\title{
Hedgehog Signaling is Associated with Liver Response to Fractionated Irradiation in Mice
}

\author{
Jieun Kim ${ }^{a}$ Sihyung Wang ${ }^{a}$ Jeongeun Hyun ${ }^{a}$ Cynthia D. Guy ${ }^{c}$ Youngmi Junga,b \\ aDepartment of Integrated Biological Science, bepartment of Biological Sciences, College of Natural \\ Science, Pusan National University, Pusan, Republic of Korea; 'Department of Pathology, Duke \\ University Medical Center, Durham, USA
}

\section{Key Words}

Hedgehog $\bullet$ Radiation-induced liver disease $\bullet$ Fractionated irradiation $\bullet$ Liver fibrosis

\begin{abstract}
Background/Aims: Radiation-induced liver disease (RILD) is a major obstacle in treating liver cancer; however, the mechanisms underlying RILD development remain unclear. Hedgehog $(\mathrm{Hh})$ orchestrates liver response to injury. Herein, we investigated the liver response with Hh to fractionated irradiation (FI) using a small murine model for RILD. Methods: Male mice exposed to liver-targeted FI with 6Gy in 5 consecutive weekly fractions were sacrificed at one day after weekly irradiation and 6 or 10 weeks post $5^{\text {th }}$ FI for the acute and late response model, respectively. Results: The levels of ALT/AST and apoptosis were elevated in all radiation groups. The expression of Hh ligand, Sonic and Indian $\mathrm{Hh}$, and $\mathrm{Hh}$ activator, smoothened and gli2, was higher in the acute groups than the control group. Pro-fibrogenic markers were also up-regulated in this model compared with the control group. Histomorphological changes and ballooned hepatocytes were observed in the late response model. Both the expression of $\mathrm{Hh}$ and profibrotic genes and the fibrosis level increased in this model compared with the control groups. Conclusion: Enhanced Hedgehog signaling and liver injury with fibrosis in RILD murine model suggests hedgehog as the potential regulator in RILD progression and the suitability of this model for studying RILD.

\section{Introduction}

Radiation therapy is one of the most effective non-surgical treatments for many cancers and is used in treating approximately $50 \%$ of cancer patients [1]. However, application of radiation therapy inevitably leads to normal tissue damage, which limits its application.

\section{KARGER}




\section{Cellular Physiology Cell Physiol Biochem 2016;40:263-276 \\ \begin{tabular}{ll|l|l} 
and Biochemistry & $\begin{array}{l}\text { DOI: 10.1159/000452543 } \\
\text { Published online: November 18, } 2016\end{array}$ & $\begin{array}{l}\text { ( ) 2016 The Author(s). Published by S. Karger AG, Basel } \\
\text { www.karger.com/cpb }\end{array}$ \\
\hline
\end{tabular} \\ Kim et al.: Hh Signaling in FI-Induced Liver Damage}

Hepatic irradiation also causes cell damage and liver dysfunction [2-4]. This radiation-induced hepatic injury occurs from two weeks to six months after irradiation and is histologically characterized by a loss of parenchymal hepatocytes and distortion of the lobular architecture, accompanied by both pericentral and periportal fibrosis [5-9]; this condition is referred to as radiation induced liver disease (RILD). RILD is one of the major complications of radiation therapy for liver cancer and is associated with a high mortality rate of patients with liver cancers $[4,10]$. Patients with RILD usually have symptoms of fatigue, hepatomegaly, ascites, and elevated liver enzymes, and these patients chronically develop liver fibrosis and failure $[2,9,11,12]$. Venous obstruction and sinusoidal congestions that are obvious in the livers of patients with RILD bring to hypoxia environment in the livers $[13,14]$. This injury results in the death of hepatocytes, accompanied by liver fibrosis and eventual hepatic dysfunction [15]. Hence, it is necessary to investigate the hepatic response to fractionated irradiation (FI) to understand the underlying mechanisms for hepatic fibrogenesis caused by FI.

Hedgehog $(\mathrm{Hh})$ is the main factor that orchestrates liver response after injury. Hepatic damage triggers the production of Hh ligands $[16,17]$. Released Hh ligands stimulate the proliferation of Hh-responsive cells such as myofibroblastic hepatic stellate cells (MF-HSCs) and progenitors, which are activated and proliferate $[16,18]$. Wang et al. showed that Hh signaling was activated and involved in the acute liver response to single-dose radiation with $20 \mathrm{~Gy}$ [19]. In addition, they subsequently demonstrated that the Hh pathway was upregulated in the late liver response to 6 Gy irradiation [20]; the Hh inhibitor blocked responses such as the proliferation of progenitor cells and the expression of fibrotic genes in the irradiated liver. These findings suggest that Hh signaling is associated with the liver's acute and late response to radiation, indicating that Hh pathway is associated with the pathogenesis of RILD. However, single follow up time 1-week post irradiation and single-dose irradiation with the relatively low dose employed in the study for the late response to radiation remain limitations in these studies. Therefore, we aimed to establish a mouse model to investigate the liver response to FI, because FI is commonly utilized in therapy for humans. We assessed the acute response at one day post every FI during fifth radiation and the late response of livers at 6 and 10 weeks after FI in order to identify the effects of radiation on chronic liver damage. Our results showed that FI promoted the proliferation of MF-HSCs, the apoptosis of hepatocytes, and the development of progressive fibrosis with activation of Hh signaling.

\section{Methods and Materials}

\section{Experimental animal model}

Six-week old male C57BL/ 6 mice were purchased from Hyochang (Dae-gu, Korea), fed a normal diet, watered, and housed with a $12 \mathrm{~h}$ light/dark cycle. The protocol used for mouse irradiation and analysis is described in Fig. 1. The mice were irradiated with ${ }^{137} \mathrm{Cs} \gamma$-rays using $\gamma$-ray irradiator (Hanil-GI, Hanil Nuclear Co., Ltd., Korea). Irradiation was limited to the upper abdomen of the mouse by a customized lead shielding of other parts of body. All mice were irradiated at the same time (3:00 p.m.) of day to eliminate any hepatic circadian variation. For the irradiation procedure, mice were anesthetized by Zoletil 50 (5 mg/kg body weight, Virbac S.A, France) to immobilize them in a recumbent position on the treatment table. Sevenweek old mice in fractionated irradiation (FI) group were exposed to liver-specific irradiation delivered in fractionated dose of 6 Gy per week for five weeks (total dose $30 \mathrm{~Gy}$ ). Mice in FI group were divided into two groups by the time of sacrifice: acute and late response. In the acute response model $(n=25)$, the mice were sacrificed one day after consecutive weekly irradiation: 1 FI ( $\left.1^{\text {st }} 6 \mathrm{~Gy}, \mathrm{n}=5\right), 2$ FI ( $\left.2^{\text {nd }} 6 \mathrm{~Gy}, \mathrm{n}=5\right), 3$ FI ( $3^{\text {rd }}$ $6 \mathrm{~Gy}, \mathrm{n}=5), 4 \mathrm{FI}\left(4^{\text {th }} 6 \mathrm{~Gy}, \mathrm{n}=5\right)$ and $5 \mathrm{FI}\left(5^{\text {th }} 6 \mathrm{~Gy}, \mathrm{n}=5\right)$ group. In the late response model $(\mathrm{n}=10)$, mice were sacrificed at 6 and 10 weeks after $5^{\text {th }}$ FI ( $n=5$ per group). Same number of non-irradiated nine-week old mice, seventeen-week old mice and twenty-one-week old mice were used as the control (CTRL) for acute and late response model, respectively (Fig. 1). To compare the age-dependent liver response among control group with seven-, nine- and eleven-week old, liver morphology, the liver and body weight, and the level of serum alanine aminotransferase (ALT)/ aspartate aminotransferase (AST) were assessed. After confirming that there was not any significant difference among control groups (data not shown), we set up 


\section{Cellular Physiology Cell Physiol Biochem 2016;40:263-276

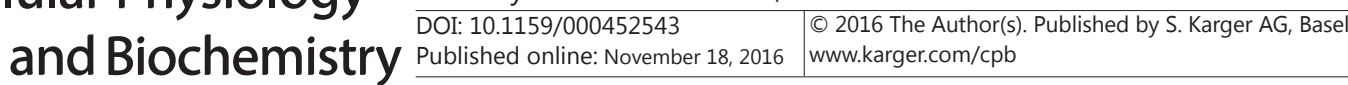 Kim et al.: Hh Signaling in FI-Induced Liver Damage}

Fig. 1. A scheme for the experimental procedure of irradiation in mice. Whole liver was irradiated with 6 Gy in 5 consecutive weekly fractions. Mice were sacrificed at one day after weekly irradiation in the acute response model and they were sacrificed at 6 or 10 weeks after 5 th irradiation in the late response model. Non-irradiated mice at 9-, 17 - and 21-weeks were used as control mice for acute and late response model, respectively.

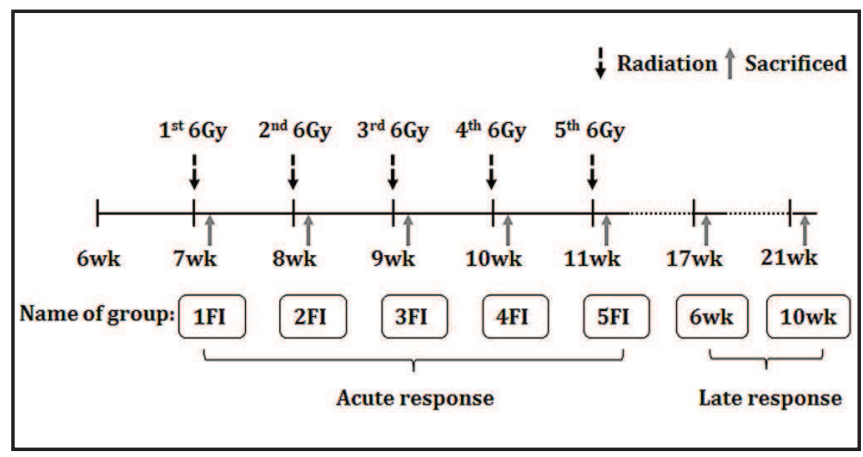

the nine-week old mice as control for acute response group. Liver tissues and serums were collected for histological and biochemical analysis. Animal care and surgical procedures were approved by the Pusan National University Institutional Animal Care and Use Committee and carried out in accordance with the provisions of the NIH Guide for the Care and Use of Laboratory Animals.

\section{RNA analysis}

Total RNA was extracted from liver tissues by using TRIzol reagent (Ambion, Life Technologies). The concentration and purity of RNA were determined using a nanodrop. Template complementary DNA was synthesized from total RNA using SuperScript II First-strand Synthesis System (Invitrogen, Life Technologies). We performed the quantitative reverse transcription polymerase chain reaction (qRT-PCR) by using Power SYBR Green Master Mix (Applied Biosystem, Life technologies) according to the manufacturer's specifications (Eppendorf, Mastercycler Real-Time PCR). All reactions were duplicated and data was analyzed according to the $\Delta \Delta \mathrm{C}_{\mathrm{t}}$ method. $40 \mathrm{~S}$ ribosomal protein $\mathrm{S} 9$ mRNA was used for normalization of the expression level. The following primer sequences were used for qRT-PCR. Mouse S9 primers, forward: GAC TCC GGA ACA AAC GTG AGG; reverse: CTT CAT CTT GCC CTC GTCCA; Mouse Shh primers, forward: GGA ACT CAC CCC CAA TTACA; reverse: TGC ACC TCT GAG TCAGC; Mouse Ihh primers, forward: GAG CTT TCC AGG TCA TCGAG; reverse: TGA TTG TCC GCA ATG AAGAG; Mouse Smo primers, forward: CAG CAA GAT CAA CGA GACCA; reverse: AAG TGG CAG CTG AAG GTGAT; Mouse Gli2 primers, forward: CAA GCA GAA CAG CGA GTCAG; reverse: CCT CAG CCT CAG TCT TGACC; Mouse TGF- $\beta$ primers, forward: TTG CCC TCT ACA ACC AAC ACAA; reverse: GGC TTG CGA CCC ACG TAGTA; Mouse Collagen $1 \alpha 1$ primers, forward: GAG CGG AGA GTA CTG GATCG; reverse: GCT TCT TTT CCT TGG GGTTC; Mouse Vimentin primers, forward: GCT TCT CTG GCA CGT TTGA; reverse: CGC AGG GCA TCG TTG TTC. All PCR products were directly sequenced for genetic confirmation in Macrogen Inc (Korea).

Western Blot analysis

Total protein was extracted from frozen liver tissue stored at $-80^{\circ} \mathrm{C}$. Samples were homogenized in Triton lysis buffer supplemented with protease inhibitors (Roche) and centrifuged at 13,000 g for 15 min. The supernatants containing protein extracts were used in subsequent biochemical analysis. For Gli2 detection, nuclear fractionation was performed. To prepare nuclear extract, cells were suspended in buffer

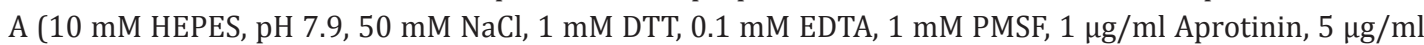
Leupeptin, and $1 \mu \mathrm{g} / \mathrm{ml}$ Pepstatin A) for 20 min on ice. An equal volume of buffer B (buffer A + 0.1\% NP-40) was then added and the suspension was allowed to sit for $20 \mathrm{~min}$ on ice. Following centrifugation at 5000 $\mathrm{g}$ for $2 \mathrm{~min}$, the supernatant cytoplasmic extract was collected and subjected to centrifugation at $5000 \mathrm{~g}$ for 2 min to remove cellular debris. Nuclear pellet was washed two times with buffer A and resuspended using buffer C (10 mM HEPES, pH 7.9, 400 mM NaCl, 1 mM DTT, 1 mM EDTA, 1 mM EGTA). After centrifugation at $15,000 \mathrm{~g}$ for $15 \mathrm{~min}$ at $4^{\circ} \mathrm{C}$, the supernatant was saved as the nuclear extract. Protein concentration was measured by Pierce BCA Protein Assay Kit (Thermo Scientific). An equal amount of protein lysates was fractionated by 8 or $10 \%$ SDS-PAGE and then transferred onto a polyvinylidene difluoride membrane (Millipore Corp., Darmstadt, Germany). Primary antibodies used in this study were as follows: rabbit antiIhh antibody (39634, Abcam), rabbit anti-Shh antibody (sc-9024, Santa Cruz Biotechnology, Inc.), rabbit antiSmo antibody (72130, Abcam), rabbit anti-Gli2 antibody (GWB-CE7858, GenWay Biotech, Inc.), rabbit antiTGF- $\beta$ (3711S, Cell Signaling Technology, Inc.), rabbit anti-collagen1a1 (NBP1-30054, Novus Biologicals), 


\section{Cellular Physiology Cell Physiol Biochem 2016;40:263-276 \begin{tabular}{ll|l} 
and Biochemistry & $\begin{array}{l}\text { DOI: 10.1159/000452543 } \\
\text { Published online: November 18, } 2016\end{array}$ & $\begin{array}{l}\text { ( ) 2016 The Author(s). Published by S. Karger AG, Basel } \\
\text { www.karger.com/cpb }\end{array}$ \\
\hline
\end{tabular} Kim et al.: Hh Signaling in FI-Induced Liver Damage}

rabbit anti-Vimentin antibody (sc-5565, Santa Cruz Biotechnology, Inc.), rabbit anti-pro Caspase-3 antibody (9662S, Cell Signaling Technology, Inc.), rabbit anti-cleaved Caspase-3 antibody (9661S, Cell Signaling Technology, Inc.), rabbit anti-Lamin $\beta 1$ antibody (ab16048, Abcam), and mouse anti-GAPDH antibody (MCA4739, AbDSerotec) were used in this experiment. Horseradish peroxidase (HRP)-conjugated antirabbit or anti-mouse IgG (Amersham ECL ${ }^{\mathrm{TM}}$, GE Healthcare) was used as secondary antibody. Protein bands were detected by EzWestLumi ECL solution (ATTO Corporation) as per the manufacturer's specifications (ATTO corporation, Ez-Capture II). The blots obtained from three independent experiments were scanned and a region of interest around the band of interest was defined. Densities of protein bands were calculated using CS Analyzer Version 2.0 (ATTO Corporation).

\section{Liver histology and immunohistochemical stain}

To examine hepatic morphology and assess liver fibrosis, standard hematoxylin and eosin (H\&E) staining and Sirius red staining were performed, respectively. Liver specimens were fixed in $10 \%$ neutral buffered formalin, embedded in paraffin, cut into $4 \mu \mathrm{m}$ sections and placed on glass slides. Sections were dewaxed with xylene, hydrated with ethanol, and stained in the usual method. For immunohistochemistry (IHC), specimens were dewaxed with xylene, hydrated with ethanol and incubated in 3\% hydrogen peroxide to block endogenous peroxidase. Antigen retrieval was performed by heating in $10 \mathrm{mM}$ sodium citrate buffer ( $\mathrm{pH} \mathrm{6.0)}$ ) for $10 \mathrm{~min}$ using microwave or applying the pepsin (Sigma-Aldrich) for $10 \mathrm{~min}$ at $37^{\circ} \mathrm{C}$. Specimens were blocked in protein block (X9090; Dako) for $30 \mathrm{~min}$ and incubated with primary antibodies at $4^{\circ} \mathrm{C}$ overnight. The following primary antibodies were used: active Caspase-3 (AF835; Novus Biologicals), Ihh (ab39634; Abcam), Gli2 (GWB-CE7858; GenWay Biotech, Inc.), Sox9 (AB5535; Millipore) and Pan-CK (Z0622; Dako). Horseradish peroxidase (HRP)-conjugated anti-rabbit (K4003; Dako) and antimouse (K4001; Dako) secondary antibodies were used to visualize target proteins. DAB reagent (K3466; Dako) was employed in the detection procedure. For K8/18-Ub co-staining, we employed double IHC staining as described previously [17, 21]. Anti-cytokeratin 8/18 (K8/18, NCL-L-5D3; Leica Biosystems), and anti-Ubiquitin (Ub, sc-8017; Santa Cruz Biotechnology, Inc.) antibodies were used and double IHC was performed as follows: following the standard application of DAB in first K8/18-staining step, the slides were washed with deionized water. To denature the antibodies of the first staining step, denaturing solution (DNS001L; Biocare Medical) was used as an elution step for preventing cross reactivity with subsequent immunohistochemical reaction. Afterwards, sections were blocked for $15 \mathrm{~min}$, incubated with second anti-Ub primary antibody for 2 hours at RT, and then secondary antibodies were used. Vina Green reagent (Biocare Medical) was applied in the second detection procedure, according to the manufacturer's recommendation. Slides were counterstained with hematoxylin for histological evaluation.

\section{Cell Counting}

To quantify the number of Pan-CK- and Sox9- positive cells, 10 portal tract (PT) areas were randomly selected per section at $40 \times$ magnification for each mouse. After excluding the major bile duct in each PT from consideration, cells staining positively for Pan-CK and Sox9 in 10 PTs per slide were counted. The PanCK- and Sox9-positive cells were quantified by counting the total number of Pan-CK or Sox9-positive cells per field and dividing by the total number of hepatocytes per field.

\section{Measurement of ALT/AST}

The levels of serum ALT (GPT, glutamate-pyruvate transaminase) and AST (GOT, glutamateoxaloacetate transaminase) were measured by using GOT/GPT measuring reagents (Asan Pharmaceutical, Seoul, Korea) according to the manufacturer's instructions.

\section{Hydroxyproline assay}

Hepatic hydroxyproline content was quantified as described previously [16, 22]. Briefly, $50 \mathrm{mg}$ of freeze-dried liver tissue was hydrolyzed in $6 \mathrm{~N} \mathrm{HCL}$ at $110^{\circ} \mathrm{C}$ for $16 \mathrm{~h}$. The hydrolysate was evaporated under vacuum and the sediment was re-dissolved in $1 \mathrm{ml}$ distilled water. Samples were filtered using 0.22 $\mathrm{mm}$ filter centrifuge tube at 18,000 g for $5 \mathrm{~min}$. Lysates were then incubated with $0.5 \mathrm{ml}$ of chloramine-T solution containing $1.41 \mathrm{~g}$ of chloramine-T dissolved in $80 \mathrm{ml}$ of acetate-citrate buffer and $20 \mathrm{ml}$ of $50 \%$ isopropyl alcohol, at room temperature (RT). After $20 \mathrm{~min}, 0.5 \mathrm{ml}$ of Ehrlich's solution, containing $7.5 \mathrm{~g}$ of dimethylaminobenzaldehyde dissolved in $13 \mathrm{ml}$ of $60 \%$ perchloric acid and $30 \mathrm{ml}$ of isopropyl alcohol was 


\section{Cellular Physiology Cell Physiol Biochem 2016;40:263-276 \begin{tabular}{ll|l} 
and Biochemistry Published online: November 18, 2016 & $\begin{array}{l}\text { ○ 2016 The Author(s). Published by S. Karger AG, Basel } \\
\text { www.karger.com/cpb }\end{array}$ \\
\hline
\end{tabular} Kim et al.: Hh Signaling in FI-Induced Liver Damage}

added to the mixture, which was incubated at $65^{\circ} \mathrm{C}$ for $15 \mathrm{~min}$. After cooling to the RT, the absorbance was read at $561 \mathrm{~nm}$. Amount of hydroxyproline in each sample was determined using the regression curve from the hydroxyproline prepared with high purity hydroxyproline (Sigma-Aldrich) and divided by the amount of liver weight contained in the initial sample $(50 \mathrm{mg})$ to get the hydroxyproline contents (mg hydroxyproline per mg liver). Data were expressed as fold changes by comparing with hydroxyproline content of the control group.

\section{Statistical Analysis}

Results are expressed as the mean \pm standard deviation (SD). Statistical differences were determined by student's t-test or one-way analysis of variance (ANOVA) using the SPSS statistics 20, followed by Scheffé's post hoc test. $P$ values $<0.05$ were considered to be statistically significant.

\section{Results}

FI induces liver damage

To induce RILD in mice, whole liver of mouse was fractionally irradiated with 6 Gy for five weeks (total dose 30 Gy) (Fig. 1). Mice in the control group were not irradiated (CTRL). Liver sections from mice treated with FI were examined for morphological changes using H\&E staining. Although necrosis was not observed in either the radiation or the control group, megamitochondria and nodular regenerative hyperplasia were apparent in the $5 \mathrm{FI}$

Fig. 2. Changes of liver histopathology and function in FI-treated mice. (A) Representative images of H\&E-stained livers $(\times 40)$. Relative liver weight/body weight (LW/BW) and the values of serum ALT and AST of mice. LW/BW ratio was presented as fold increase compared to control mice. Mean \pm $S D$ results are graphed ( $n \geq 4$ mice) group) ANOVA, *p<0.05 vs. control). (B) Immunoblots and band densities of pro- and cleaved caspase-3 and in FI-treated mice. Band densities were expressed as fold increase compared to control. Mean \pm SD results are graphed (ANOVA, ${ }^{*} \mathrm{p}<0.05$ vs. control). (C) Representative images of IHC for active caspase- 3 in liver sections from representative mice from each groups $(\times 40)$. (C or CTRL: Control / FI: Fractionated irradiation).

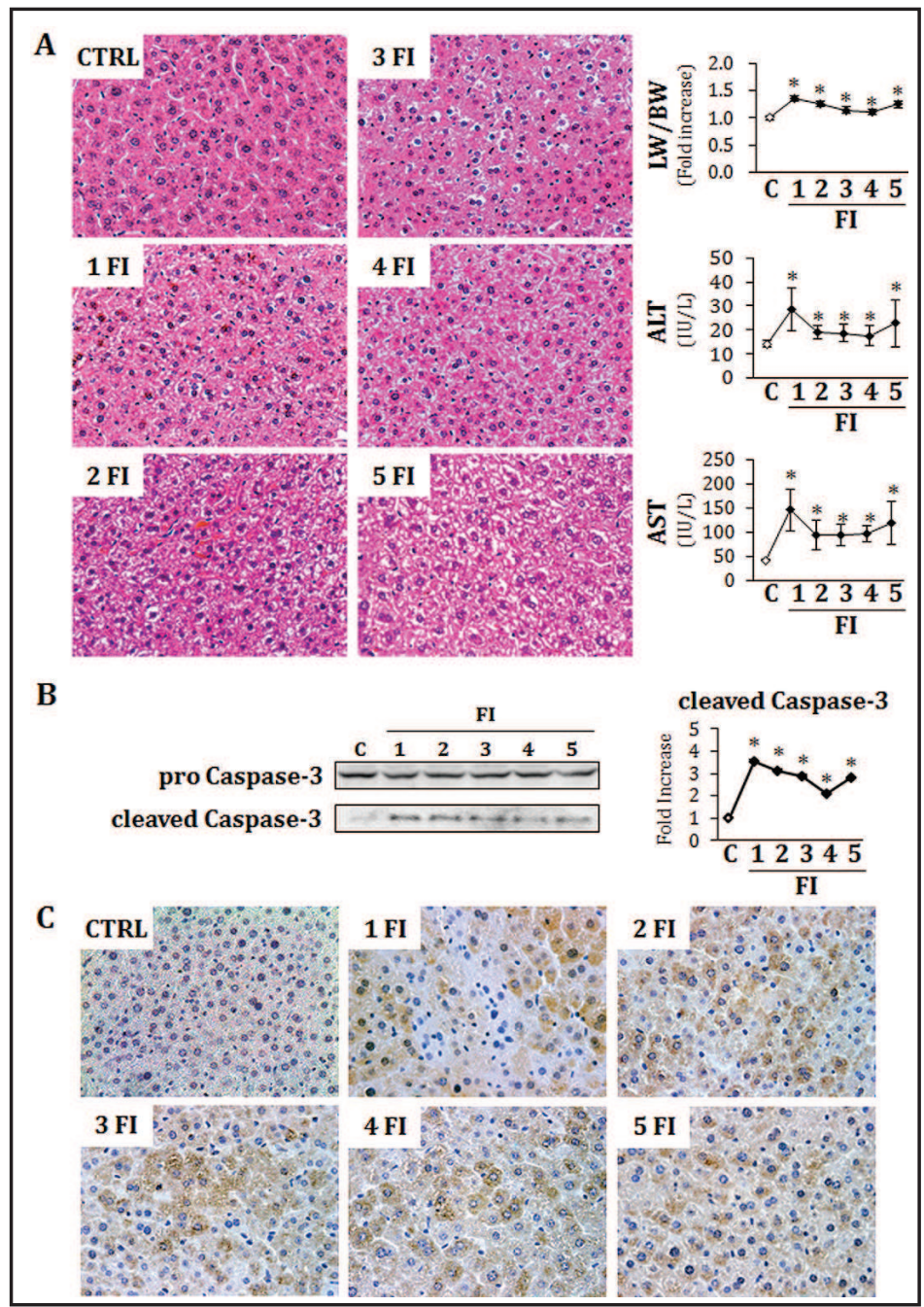




\section{Cellular Physiology \\ Cell Physiol Biochem 2016;40:263-276 \\ \begin{tabular}{|l|l|l|l|l|l|}
\hline DOI: 10.1159/000452543 & (c) 2016 The Author(s). Published by S. Karger AG, Base
\end{tabular} and Biochemistry Published online: November 18, 2016 www.karger.com/cpb \\ Kim et al.: Hh Signaling in FI-Induced Liver Damage}

Fig. 3. Increased expression of Hh ligand in livers of FI-treated mice. (A) qRT-PCR analysis of liver mRNA for shh and ihh $(\mathrm{n} \geq 3$ mice/ group). All the mRNA levels were normalized with S9 ribosomal and expressed as fold increase compared with control. Mean \pm SD results are graphed (ANOVA, ${ }^{*} \mathrm{p}<0.05$ vs. control). (B and C) Western blot analysis of Shh and Ihh (GAPDH was used as an internal control). Data shown represent one of three experiments with similar results. Band densities were expressed as fold increase compared to control. Mean \pm SD results are graphed (ANOVA, ${ }^{*} \mathrm{p}<0.05$ vs. control). (B: Immunoblot/C: Band density) (D) IHC for Ihh (brown-color) in liver sections from representative mice from each group $(\times 40)$. Ihh-positive hepatic oval- and stellate-looking cells were indicated by arrowhead and arrow, respectively. (C or CTRL: Control / FI: Fractionated irradiation).

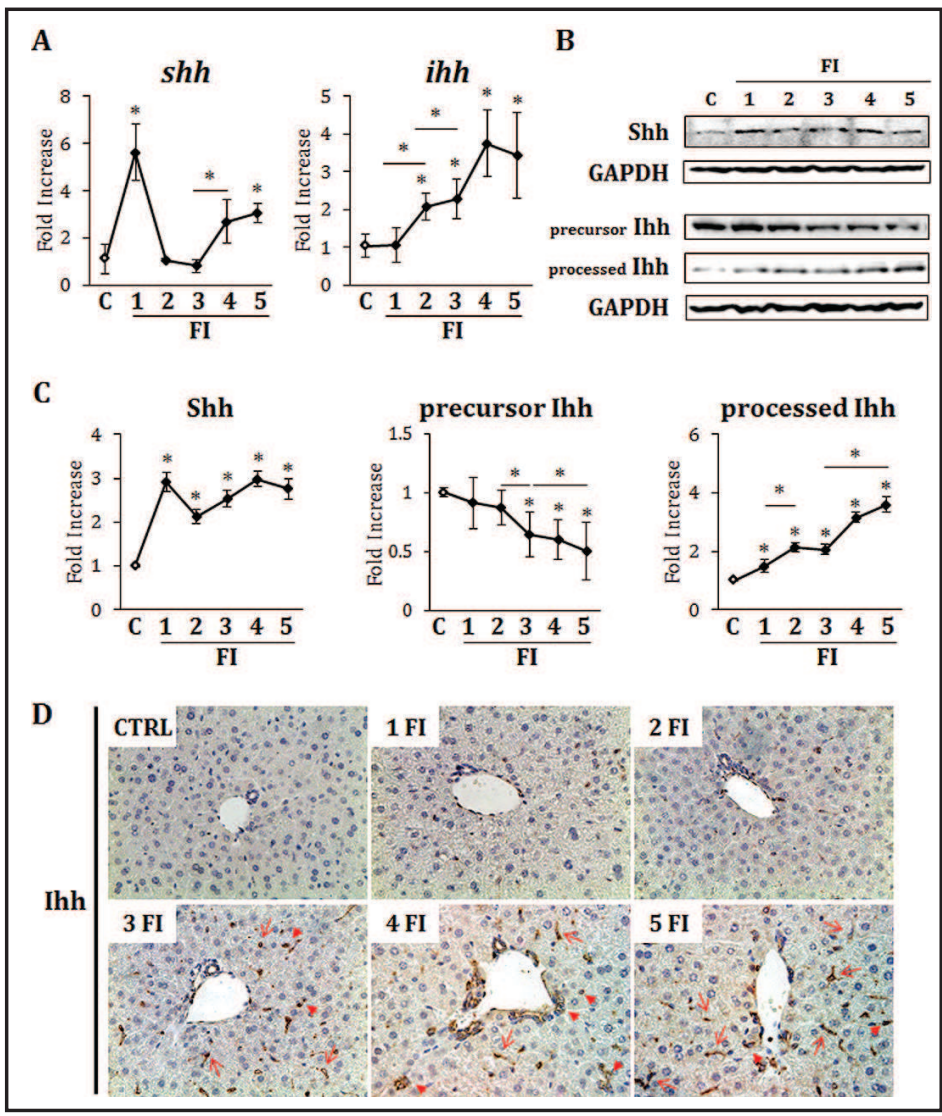

group. The relative liver weight/body weight (LW/BW) ratio was continuously upregulated in all radiation groups compared with the control group. The levels of serum ALT and AST were also higher in the irradiated mice than in the control mice. Interestingly, those levels peaked at the first irradiation, steadily declined by the fourth radiation, then increased again by the fifth radiation (Fig. 2A). To probe the link between these morphophysiological changes and hepatic damage, we investigated the level of apoptosis in the irradiated liver. Similar to the results relating to LW/BW, ALT, and AST, the expression of cleaved Caspase-3, an activated apoptotic marker, increased, peaking at almost 4-fold above basal levels at first radiation in the radiation group, as assessed by western blot (Fig. 2B). IHC staining for active Caspase-3 confirmed the enhanced apoptosis in the liver section of the FI group (Fig. 2C). These results suggest that the acute liver damage occurred in response to the repetitive exposure of radiation.

\section{Hedgehog signaling activated in FI-treated livers of mice}

Because Hh signaling was shown to be involved in acute and chronic liver response to irradiation in previous studies $[19,20]$, we assessed whether and how Hh signaling was activated in the FI-treated livers of mice. Sonic Hh, one of the Hh ligands, was upregulated, peaking at almost 6 -fold above basal levels at first irradiation before being rapidly downregulated back to nearly basal level at second and third irradiation, as examined by qRTPCR. This RNA level of Shh was increased again at the fourth and fifth irradiation (Fig. 3A). Western blot analysis showed the continuative increase of Shh during radiation (Fig. 3B and 3C). It appears that the elevated level of Shh protein in the 2 FI and 3 FI groups might be induced by robust RNA production of $s h$ at the first radiation. Another Hh ligand, Indian Hh (Ihh), showed a steady increase in both RNA and protein levels. Interestingly, precursor Ihh showed the number of irradiation-dependent decrease, whereas processed Ihh (the active form of Ihh) [22] showed the number of irradiation-dependent increase in the FI 


\section{Cellular Physiology Cell Physiol Biochem 2016;40:263-276 \begin{tabular}{ll|l} 
and Biochemistry Published online: November 18, 2016 & $\begin{array}{l}\text { ○ 2016 The Author(s). Published by S. Karger AG, Basel } \\
\text { www.karger.com/cpb }\end{array}$ \\
\hline
\end{tabular} Kim et al.: Hh Signaling in FI-Induced Liver Damage}

Fig. 4. Up-regulation of Hh-target genes in irradiated mice. (A and $\mathrm{B}$ ) Western blot analysis of Smo and Gli2 (GAPDH or Lamin $\beta 1$ was used as an internal control). Data shown represent one of three experiments with similar results. Band densities were expressed as fold increase compared to control. Mean \pm SD results are graphed (ANOVA, ${ }^{*} \mathrm{p}<0.05$ vs. control). (A: Immunoblot/B: Band density). (C) Representative image of IHC for Gli2 (brown-color) in liver sections from representative mice from each group $(\times 40)$. Magnified image in right panel is shown at $\times 100$. (C or CTRL: Control / FI: Fractionated irradiation).

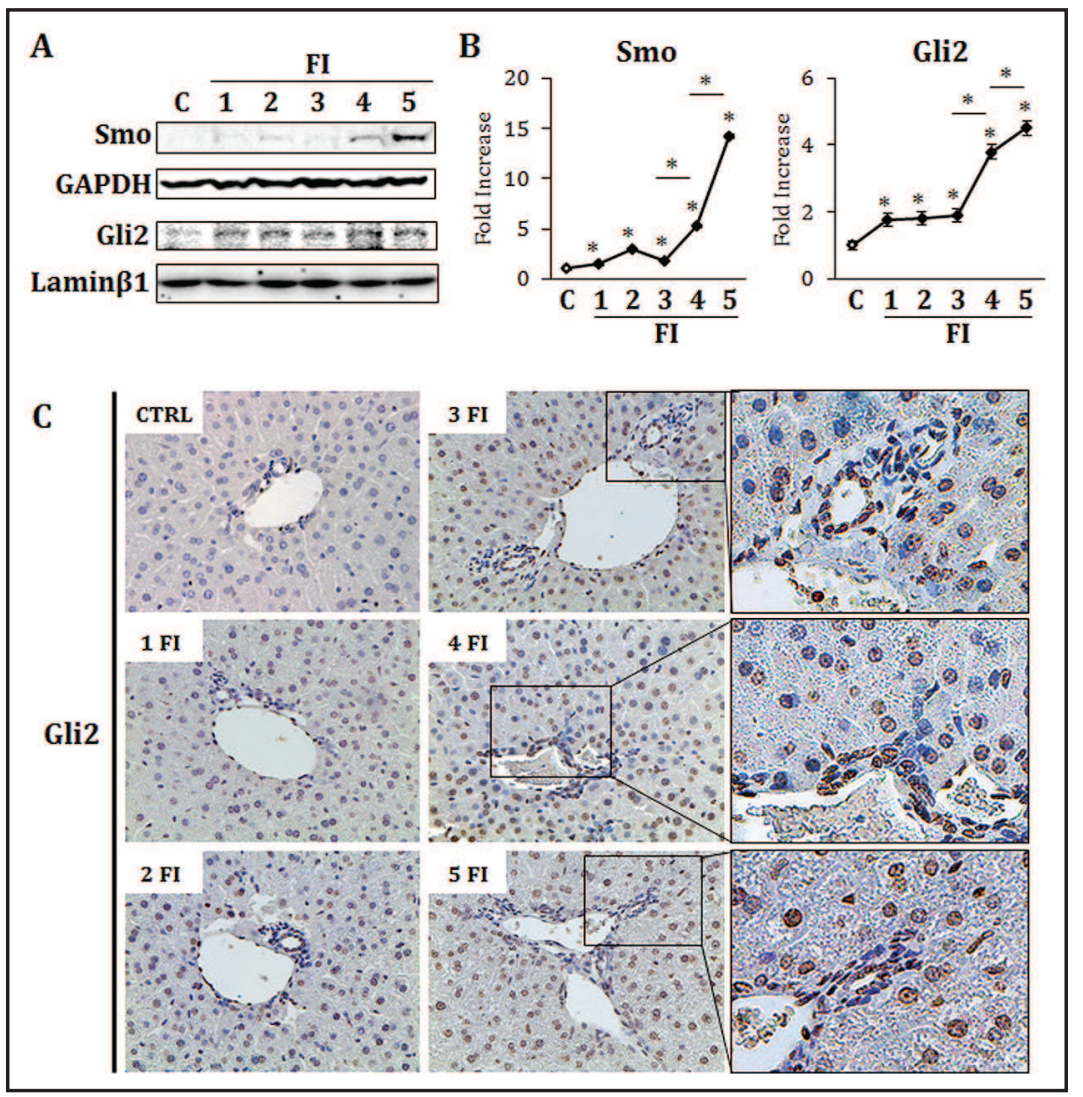

group (Fig. 3A-3C). In addition, Ihh-positive HSCs (indicated by arrows) and progenitor-like cells (indicated by arrowheads) were apparently observed after third FI, as assessed by IHC (Fig. 3D). As the expression of Hh ligands increased, Hh activators, Smoothened (Smo), Hh receptor, and Gli2, Hh-target gene, were upregulated in FI compared with the control group. Both Smo and Gli2 proteins showed a rapid increase at fourth FI and kept more elevation at fifth FI, in accordance with the sharp increase of Hh ligands (Fig. 4A and 4B). Interestingly, IHC staining for Gli2 showed the transition of Gli2-positive cells from Gli2-positive ductular cells into Gli2-positive hepatocyte-like cells as the number of irradiations increased (Fig. 4C). Because healthy hepatocytes are known to rarely express Gli2 [23, 24] and these Gli2positive hepatocyte-like cells might be derived from Gli2-positive progenitors [16, 25]. In the present studies, we found that progenitors-positive for pancytokeratin or Sox 9 were accumulated in the irradiated livers, and the number of these cells increased during FI (Fig. 5). Hence, these results suggest that the Hh signaling activated by FI induced the expansion of Hh-responsive progenitors, which might differentiate into hepatocytes in response to repetitive radiation exposure.

\section{Hepatic fibrosis induced in FI-treated liver}

$\mathrm{Hh}$ is a well-known factor regulating hepatic fibrosis [26, 27]. Given that the Hh pathway was activated during FI treatment, we investigated whether hepatic fibrosis occurred in the livers of FI-treated mice. The level of transforming growth factor $\beta$ (TGF- $\beta$ ), a wellknown fibrotic promoter, and the fibrotic markers, collagen $1 \alpha 1$ (col1 $\alpha 1$ ) and vimentin, were upregulated in all radiation groups, showing the tendency of frequency-dependent increase (Fig. 6A and 6B). Sirius Red staining also demonstrated that FI-treated mice had more pericellular and sinusoidal deposition of collagen fibrils after the third irradiation than the control mice (Fig. 6C). Hepatic hydroxyproline content, a quantitative measure of liver fibrosis, confirmed that the FI group had significantly more liver fibrosis than the control 


\section{Cellular Physiology \\ Cell Physiol Biochem 2016;40:263-276

Fig. 5. Accumulation of hepatic progenitors during FI. (A) IHC for Pan-CK and Sox9 in liver sections from representative mice from each group. The representative images are shown at $\times 40$. (B) Quantitative Pan-CK and Sox9 stained data from all mice $(n=4$ mice/group). Pan-CK or and Sox9- positive cells were quantified by counting the total number of Pan-CK or and Sox9- positive cells per field and dividing by the total number of hepatocytes per field. Quantitative Pan-CK or Sox9 data was presented as fold increase compared with control. Mean \pm SD results are graphed (ANOVA, *p<0.05 vs. control). (C or CTRL: Control / FI: Fractionated irradiation).

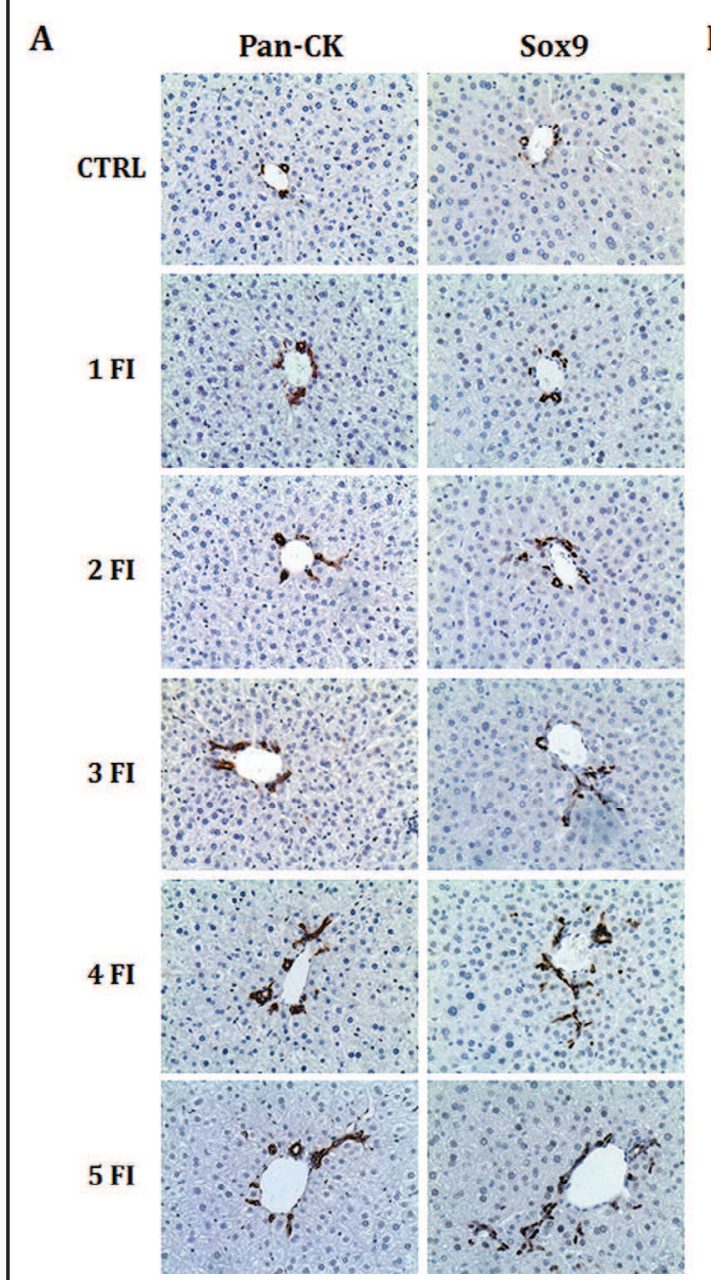

B
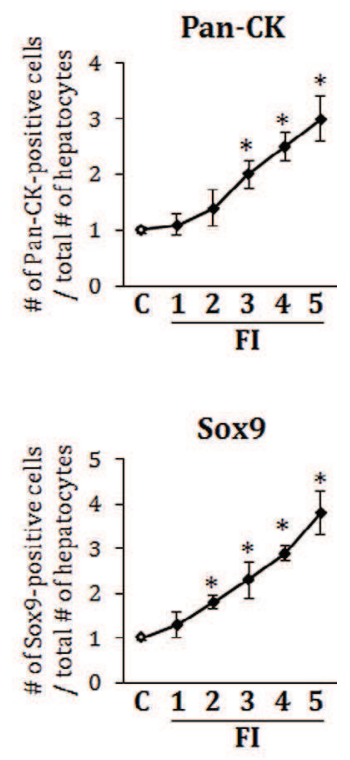

group, presenting that the level of fibrosis increased with radiation frequency (Fig. 6D). These data suggest that FI promoted the progressive fibrogenesis in the livers of mice.

FI-induced severe hepatic injury with fibrosis in late response model of RILD

In the liver's acute response to FI, hepatic damage was induced as Hh signaling was activated, and the expression of profibrotic genes increased. To confirm whether the activated Hh pathway influenced the late response to radiation, we sacrificed mice at 6 and 10 weeks after the last exposure to radiation. H\&E staining showed the accumulation of apoptotic hepatocytes and spotty necrosis in liver sections at both 6 and 10 weeks. Interestingly, ballooned hepatocytes showing mallory bodies (MB) started to be observed at the $6 \mathrm{wk}$ group and were accumulated in the 10 wk group. Double IHC for cytokeratin 8/18 and ubiquitin confirmed the MBs in the hepatocytes in these groups, indicating severe injury in hepatocytes in the late response to FI (Fig. 7A). In consistency with the histological severity in the late response model, LW/BW increased in the $6 \mathrm{wk}$ group and then decreased in the 10 wk group compared with the control group. The levels of ALT and AST in the radiation group were higher than that in the control group (Fig. 7B). In addition, the content of hydroxyproline in the irradiated mice was significantly higher than in the control mice (Fig. 7C). Sirius Red staining displayed the elevated deposition of collagen fibrils in parenchymal areas compared with control group (Fig. 7D). These findings indicate that hepatic injury appears to be progressive, reflecting the chronic response to radiation.

Expression of Hh ligands, shh and $i h h$, and Hh target genes, smo and gli2, were significantly higher in both 6 and 10 wk group than in the control group. (Fig. 8A). In 


\section{Cellular Physiology Cell Physiol Biochem 2016;40:263-276 \begin{tabular}{ll|l} 
and Biochemistry & $\begin{array}{l}\text { DOI: 10.1159/000452543 } \\
\text { Published online: November 18, } 2016\end{array}$ & $\begin{array}{l}\text { ( ) 2016 The Author(s). Published by S. Karger AG, Basel } \\
\text { www.karger.com/cpb }\end{array}$ \\
\hline
\end{tabular} Kim et al.: Hh Signaling in FI-Induced Liver Damage}
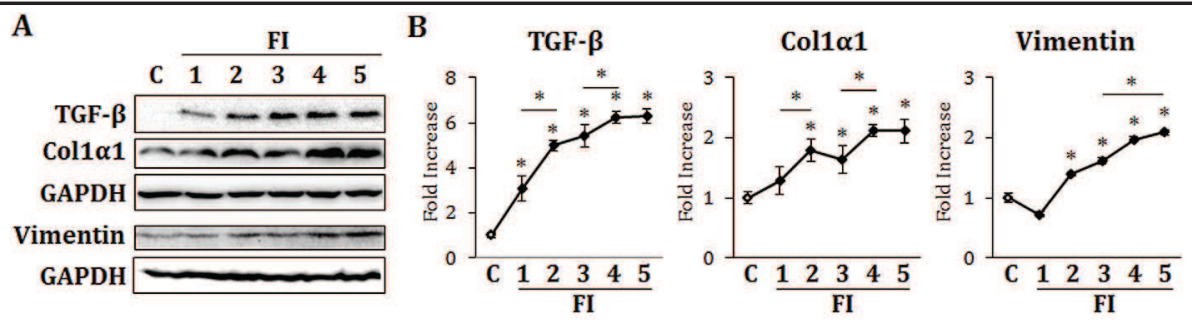

C

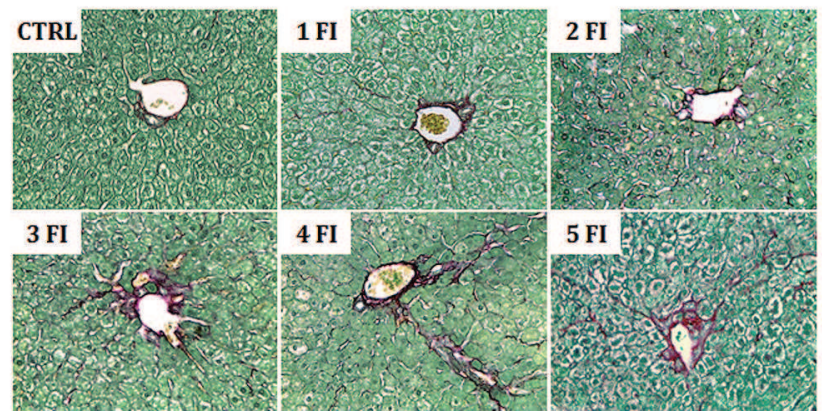

D

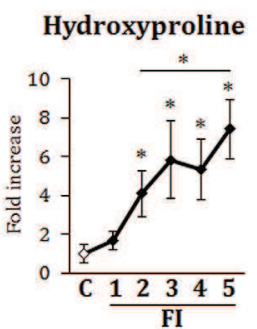

Fig. 6. Progressive deposition of fibrosis in the FI-treated livers. (A and B) Western blot analysis of TGF- $\beta$, Col1 $\alpha 1$ and Vimentin (GAPDH was used as an internal control). Data shown represent one of three experiments with similar results. Band densities were expressed as fold increase compared with the control group. Mean \pm SD results are graphed (ANOVA, ${ }^{*} p<0.05$ vs. control). (A: Immunoblot/B: Band density) (C) Sirius red staining in liver sections from each group. ( $n \geq 3$ mice/group). Representative images are shown (X40) (D) Relative level of hydroxyproline contents ( $\mathrm{n} \geq 3$ mice/group). Data were expressed as fold increase compared with control. Mean \pm SD results are graphed (ANOVA, ${ }^{*} \mathrm{p}<0.05$ vs. control). (C or CTRL: Control / FI: Fractionated irradiation).

addition, the expression of fibrotic factors, $\operatorname{tg} f-\beta, \operatorname{col} 1 \alpha 1$ and vimentin, significantly increased at both 6 and 10 wk groups compared with the control group (Fig. 8B). Therefore, these results indicate that the activated Hh signaling triggered by FI influences the development of progressive fibrogenesis by upregulating profibrogenic factors, contributing to late-onset fibrosis in RILD.

\section{Discussion}

Radiation-induced fibrosis is the major chronic radiation damage in multiple organs, including the skin, lung, and gastrointestinal tract $[28,29]$. Although radiation fibrosis has been the focus of many clinical studies, the mechanisms of its initiation and development remain unknown. In addition, there are no efficient therapies for the treatment of radiationinduced liver fibrosis. Clinically, radiation-induced liver complications are typically divided into two types, incipient RILD and late fibrosis, depending on when it first occures [30, 31]. Incipient RILD is usually diagnosed 4 to 8 weeks after completion of treatment, while the late fibrosis tends to manifest more than 3 months after treatment. RILD, including late fibrosis, is becoming an increasingly serious problem with a large population of long-term survivors $[3,10,14]$. Hence, investigation of the progression of the tissue damage that occurs after radiation therapy is very important for understanding the pathophysiological mechanism of RILD and its prevention, eventually contributing to the treatment efficacy of radiotherapy. In previous studies, Hh has been shown to be related with liver fibrosis after single radiation $[19,20]$. In the current research, we found that subsequent exposure to radiation evoked the progressive activation of the Hh pathway and a fibrogenic response. This activation was still persistent in the livers of mice at 6 and 10 weeks after fifth irradiation, indicating that $\mathrm{Hh}$ 


\section{Cellular Physiology Cell Physiol Biochem 2016;40:263-276 \begin{tabular}{ll|l} 
and Biochemistry $10.1159 / 000452543$ & $\begin{array}{l}\text { Published online: November 18, } 2016 \\
\text { www.karger.com/cpb }\end{array}$ \\
\hline
\end{tabular} Kim et al.: Hh Signaling in FI-Induced Liver Damage}

Fig. 7. Hepatic injury in late response model of FI. (A) Representative images of H\&E-stained or double, K8/18 (brown) and Ubiquitin (green), stained livers of mice at 6 and 10 weeks (H\&E: $\times 40$, double IHC: $\times 63$ ). Mallory bodies are indicated by arrowheads and magnified in the inserted image (×100). (B) Relative LW/BW ratio and the value of serum ALT/AST level ( $\mathrm{n} \geq 3$ mice/group). Mean \pm SD results are graphed (unpaired two-sample Student's t-test, ${ }^{*} \mathrm{p}<0.05,{ }^{*} \mathrm{p}<0.005$ vs. own control). (C) Hydroxyproline contents. Mean \pm SD results are graphed ( $\mathrm{n} \geq 3$ mice/group) (unpaired two-sample Student's t-test, ${ }^{*} \mathrm{p}<0.05$, ${ }^{* *} \mathrm{p}<0.005$ vs. own control). (D) Sirius red staining in liver sections from representative mice from each group $(\times 40)$. (CTRL; age-match control / IR; mice at 6 or 10 wks post fifth FI).

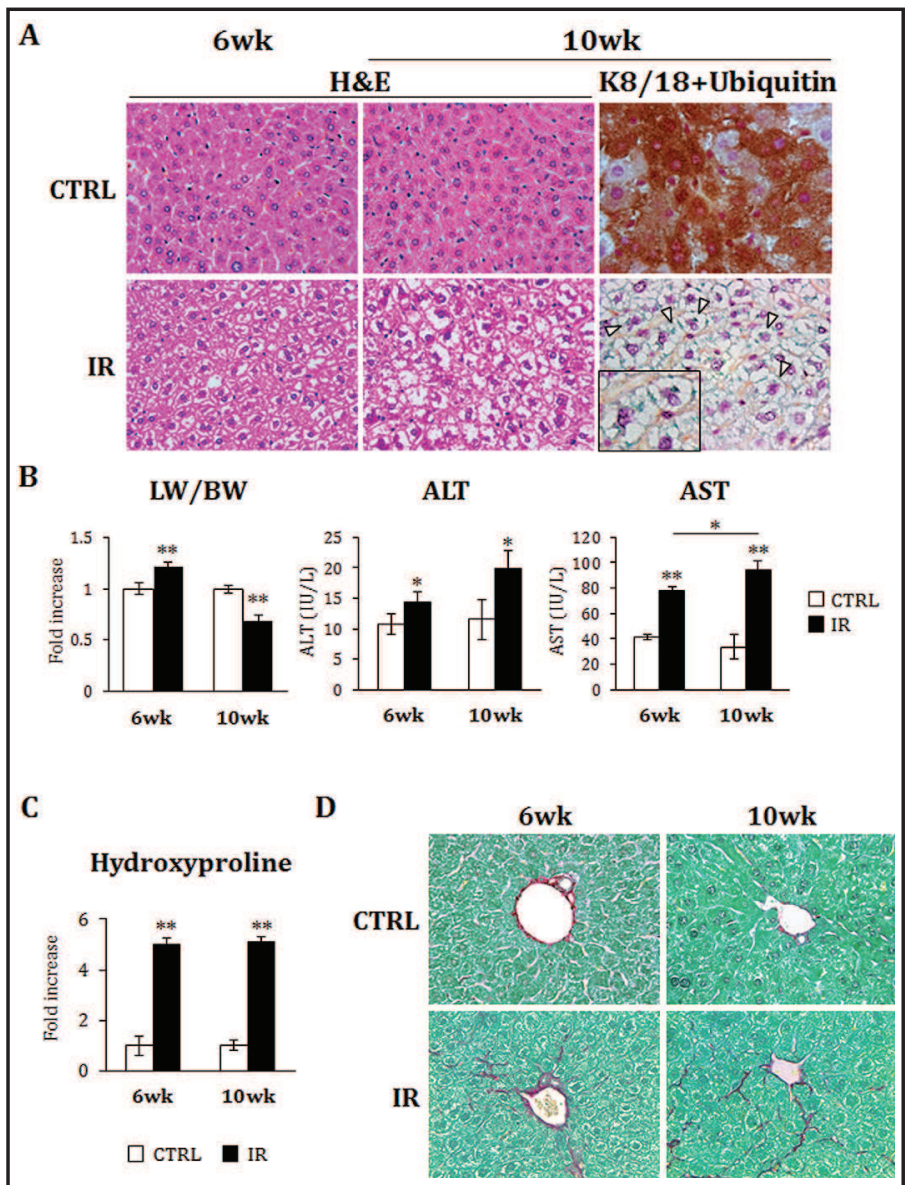

signaling was associated with the accumulation of fibrosis in the late hepatic response in the 6- and 10-week radiation groups.

In mammals, circadian rhythms synchronize a broad range of physiological processes with environmental conditions, such as eating and sleeping pattern. It is well-known that the body's molecular clock has an impact on the liver by regulating its cellular and physiological functions in a specific way [32]. The liver-circadian clock system rapidly responds to nutrient and hormone signalling to regulate metabolism and energy homeostasis, as well as detoxification and liver repair [33, 34]. It has been reported that the livers of irradiated mice show distinct circadian variations, such as hepatic enzyme activity, liver proliferation, cell cycle and transcriptional responses [35-37]. Furthermore, circadian dysregulation in the liver has been shown to be closely associated with liver diseases, including liver steatosis, fibrosis, and even carcinogenesis, and these diseases are also affected by the disrupted circadian clocks [38, 39]. Hence, liver-related animal experiments must be designed and conducted carefully to not negatively impact this system. In the current study, we irradiated the mice at the same time to eliminate any hepatic circadian variation.

It was expected that the level of response would increase in line with an increase in the number of irradiation treatments. However, the ratio of LW/BW and serum ALT/AST levels was strikingly increased at the first FI and then declined gradually until the fourth FI. It is possible that the liver is hyperactivated, rapidly triggering the repair process as soon as the quiescent liver is stimulated by the first FI. This abrupt response subsequently declined and maintained a steady level by the second FI; the liver appeared to recognize the damage and perform appropriate repairs [40]. The apoptosis level and Shh expression changes in the liver of the FI groups supported this explanation. Cumulative injury again augmented the ratio of LW/BW and serum ALT/AST levels at the fifth FI, indicating that liver damage by radiation might exceed the threshold ability of liver repair and trigger dysregulated repair 


\section{Cellular Physiology \\ Cell Physiol Biochem 2016;40:263-276 \\ \begin{tabular}{l|l}
\hline DOI: 10.1159/000452543 & (c) 2016 The Author(s). Published by S. Karger AG, Basel
\end{tabular} and Biochemistry Published online: November 18, 2016 年 $\begin{aligned} & \text { 2016 The Author(s). } \\ & \text { wwer.com/cpb }\end{aligned}$ \\ Kim et al.: Hh Signaling in FI-Induced Liver Damage}

Fig. 8. QRT-PCR analysis of Hh and fibrotic markers in late $\mathbf{A}$ response model of FI. (A and B) qRT-PCR analysis for $\mathrm{Hh}$ signaling (shh, ihh, smo, and gli2) and pro-fibrogenic markers (tgf- $\beta$, col1 $\alpha 1$, and vimentin) ( $\mathrm{n} \geq 3$ mice/group). All the mRNA levels were normalized with S9 ribosomal and expressed as fold increase compared with own control. Mean \pm SD results are graphed (unpaired two-sample Student's t-test, ${ }^{*} \mathrm{p}<0.05, \quad{ }^{* *} \mathrm{p}<0.005$ vs. own control) (CTRL; age-match control / IR; mice at 6 or $10 \mathrm{wks}$ post fifth FI).

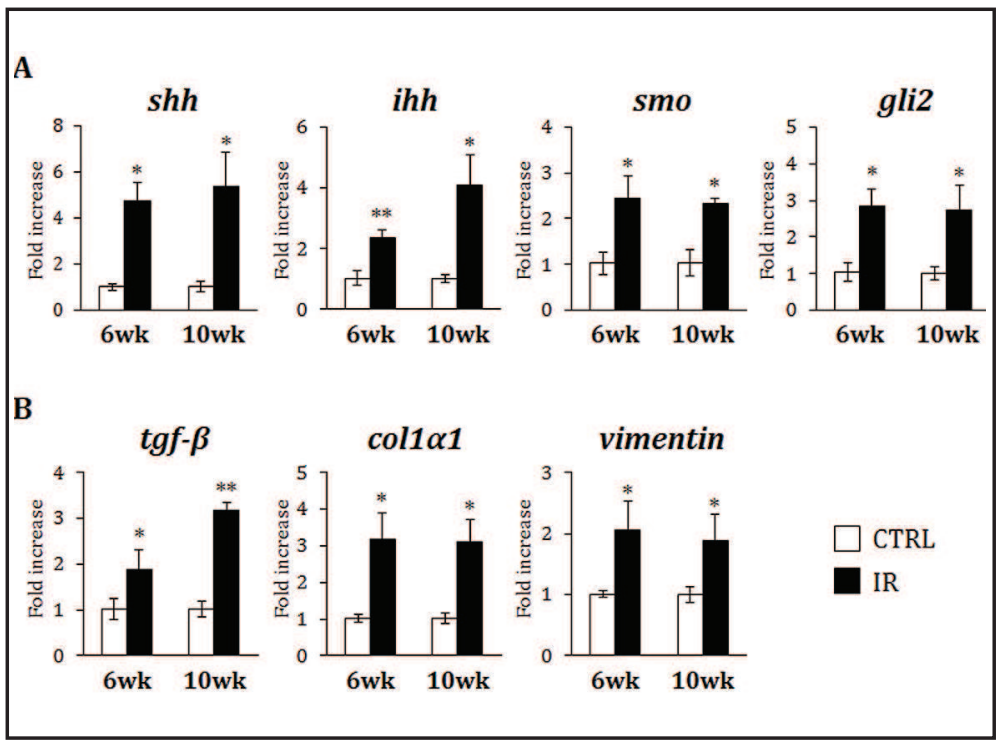

process. Notably, fibrosis and expansion of progenitors constantly increased during FI. Thus, hepatic irradiation appears to cause a loss of regenerative capacity, and it may render an irradiated liver incapable of preventing hepatic disorders.

In the injured liver, apoptotic hepatocytes release Shh and Ihh and stimulate Hhresponsive cells, such as progenitors or HSCs $[16,18]$. These cells also express Hh ligands in an autocrine manner and promote a remodeling response to liver injury $[17,41]$. In our FI model, the Hh ligands, Shh and Ihh, showed different patterns of expression. Shh showed an immediate increase in response to the first FI exposure and sustained its expression, whereas active Ihh showed a gradual increase in the number of irradiation-dependent manner. It seems that Shh and Ihh might be early and late IR-responsive genes, respectively, and that they have distinct roles in response to hepatic injury [22, 42]. In line with our findings, Jen et al. reported that the temporal transcriptional response of genes to radiation differed depending on their functions [43].

Our understanding of RILD derives mostly from clinical observations [5, 44, 45] and patient-derived histopathology $[46,47]$ due to the lack of a suitable animal model showing histological characteristics similar to humans, especially veno-occlusive disease (VOD) [9]. VOD in the human liver occurs as a result of radiotherapy [9], chemotherapy [48], or certain plant alkaloids $[49,50]$. In experimental animal models, VOD has been reported to be generated by non-radiation factors, toxins, and drugs. For example, monocrotalin and 5-thioguanine were reported to induce VOD in rats [51] and mice [52], respectively. A combination of whole body radiation with a low-protein diet-induced liver necrosis and fibrosis, but not VOD, in rats [53], whereas the combination of radiation and chemotherapy induced VOD in dogs [54]. Although several chemical or combined methods cause RILD or VOD-like damage in animals, a single method with hepatic irradiation rarely generates VOD in rodents [55, 56], dogs [57], or rhesus monkeys [58]. Importantly, one recent study showed that hypo-fractionated liver irradiation generated hepatic venous injury similar to human VOD in a cynomolgus monkey [59]. They also observed the elevated alkaline phosphatase, parenchymal congestion, and sinusoidal fibrosis seen in human VOD. However, although monkey models have an advantage of being biological similar to humans, their long life span, the high cost of studies, and lower accessibility constitute a major burden for scientists seeking to conduct experiments. Therefore, small animal models (e.g., murine models) are essential for investigating and elucidating the mechanisms of RILD. In the present study, we generated a murine model that mimics human RILD and examined the effect of FI on the liver. Although we did not observe VOD, a typical histological characteristic in human RILD, in this experimental mouse model, the FI-treated mice in the acute response model showed 


\section{Cellular Physiology Cell Physiol Biochem 2016;40:263-276 \begin{tabular}{l|l|l}
\hline DOI: 10.1159/000452543 & (c) 2016 The Author(s). Published by S. Karger AG, Basel
\end{tabular} and Biochemistry Published online: November 18, 2016 www.karger.com/cpb \\ Kim et al.: Hh Signaling in FI-Induced Liver Damage}

physiological changes in line with elevated levels of apoptosis and fibrosis; the 5 FI groups also showed morphological changes (Fig. 2 and 6). In addition, as shown in Fig. 7, FI induced further morphological changes with a loss of parenchymal hepatocyte and the excess fibrosis in the late response FI model. These responses were induced by radiation treatment only, not in combination with non-radiation factors. These results suggest that this murine model has potential as a resource for investigating the pathogenetical mechanisms in the early and late phases of RILD.

In conclusion, we have showed that Hh signaling is activated in response to FI and promotes progressive fibrogenesis in the livers of mice with incipient RILD. In the late response model in our study, severe hepatic damage with apoptotic hepatocytes was observed, accompanied by continuous activation of Hh signaling and fibrosis, reflecting the late fibrotic response to radiation. Therefore, our results suggest that this small murine model is suitable for studying RILD and that Hh signaling is a promising target for the development of new therapeutics to improve the efficiency of radiotherapy in the liver.

\section{Acknowledgements}

This work was supported by the National Research Foundation of Korea (NRF) grant funded by the Koreagovernment(MEST) awarded to YoungmiJung(No.2014M2B2A9030333).

\section{Disclosure Statement}

The authors state no conflict of interest.

\section{References}

1 Delaney G, Jacob S, Featherstone C, Barton M: The role of radiotherapy in cancer treatment: estimating optimal utilization from a review of evidence-based clinical guidelines. Cancer 2005;104:1129-1137.

2 Lawrence TS, Robertson JM, Anscher MS, Jirtle RL, Ensminger WD, Fajardo LF: Hepatic toxicity resulting from cancer treatment. Int J Radiat Oncol 1995;31:1237-1248.

3 Hawkins MA, Dawson LA: Radiation therapy for hepatocellular carcinoma: from palliation to cure. Cancer 2006;106:1653-1663.

4 Wigg AJ, Palumbo K, Wigg DR: Radiotherapy for hepatocellular carcinoma: systematic review of radiobiology and modeling projections indicate reconsideration of its use. J Gastroenterol Hepatol 2010;25:664-671.

5 Shulman HM, McDonald GB, Matthews D, Doney KC, Kopecky KJ, Gauvreau JM, Thomas ED: An analysis of hepatic venocclusive disease and centrilobular hepatic degeneration following bone marrow transplantation. Gastroenterology 1980;79:1178-1191.

6 DeLeve LD, Shulman HM, McDonald GB: Toxic injury to hepatic sinusoids: sinusoidal obstruction syndrome (veno-occlusive disease): Semin Liver Dis 2002;22:27-42.

7 da Silveira EB, Jeffers L, Schiff ER: Diagnostic laparoscopy in radiation-induced liver disease. Gastrointest Endosc 2002;55:432-434.

8 Sempoux C, Horsmans Y, Geubel A, Fraikin J, Van Beers BE, Gigot JF, Lerut J, Rahier J: Severe radiationinduced liver disease following localized radiation therapy for biliopancreatic carcinoma: activation of hepatic stellate cells as an early event. Hepatology 1997;26:128-134.

9 Reed Jr G, Cox Jr A: The human liver after radiation injury. A form of veno-occlusive disease. Am J Pathol 1966;48:597-611.

10 Guha C, Kavanagh BD: Hepatic radiation toxicity: avoidance and amelioration. Semin Radiat Oncol 2011;21:256-263.

11 Fajardo LF, Colby TV: Pathogenesis of veno-occlusive liver disease after radiation. Arch Pathol Lab Med 1980;104:584-588. 


\section{Cellular Physiology Cell Physiol Biochem 2016;40:263-276 \begin{tabular}{rl|l} 
and Biochemistry $10.1159 / 000452543$ & $\begin{array}{l}\text { D 2016 The Author(s). Published by S. Karger AG, Basel } \\
\text { Published online: November 18, } 2016\end{array}$ & \begin{tabular}{l} 
www.karger.com/cpb \\
\hline
\end{tabular}
\end{tabular} Kim et al.: Hh Signaling in FI-Induced Liver Damage}

12 Ogata K, Hizawa K, Yoshida M, Kitamuro T, Akagi G, Kagawa K, Fukuda F: Hepatic injury following irradiation-A morphologic study. Tokushima J Exp Med 1963;43:240-251.

13 Robbins M, Zhao W: Chronic oxidative stress and radiation-induced late normal tissue injury: a review. Int J Radiat Biol 2004;80:251-259.

14 Wang BF, Wang XJ, Kang HF, Bai MH, Guan HT, Wang ZW, Zan Y, Song LQ Min WL, Lin S, Cheng YA: Saikosaponin-D enhances radiosensitivity of hepatoma cells under hypoxic conditions by inhibiting hypoxia-inducible factor- $1 \alpha$. Cell Physiol Biochem 2014;33:37-51.

15 Losser MR, Payen D: Mechanisms of liver damage. Semin Liver Dis 1996;16:357-367.

16 Jung Y, Witek RP, Syn W-K, Choi SS, Omenetti A, Premont R, Guy CD, Diehl AM: Signals from dying hepatocytes trigger growth of liver progenitors. Gut 2010;59:655-665.

17 Rangwala F, Guy CD, Lu J, Suzuki A, Burchette JL, Abdelmalek MF, Chen W, Diehl AM: Increased production of sonic hedgehog by ballooned hepatocytes. J Pathol 2011;224:401-410.

18 Chen Y, Choi SS, Michelotti GA, Chan IS, Swiderska-Syn M, Karaca GF, Xie G, Moylan CA, Garibaldi F, Premont R: Hedgehog controls hepatic stellate cell fate by regulating metabolism. Gastroenterology 2012;143:13191329.e1-11.

19 Wang S, Hyun J, Youn B, Jung Y: Hedgehog signaling regulates the repair response in mouse liver damaged by irradiation. Radiat Res 2012;179:69-75.

20 Wang S, Lee Y, Kim J, Hyun J, Lee K, Kim Y, Jung Y: Potential role of Hedgehog pathway in liver response to radiation. PLoS One 2013;8:e74141.

21 Guy CD, Suzuki A, Burchette JL, Brunt EM, Abdelmalek MF, Cardona D, McCall SJ, Unalp A, Belt P, Ferrell LD, Diehl AM: Costaining for keratins 8/18 plus ubiquitin improves detection of hepatocyte injury in nonalcoholic fatty liver disease. Hum Pathol 2012;43:790-800.

22 Hyun J, Wang S, Kim J, Kim GJ, Jung Y: MicroRNA125b-mediated Hedgehog signaling influences liver regeneration by chorionic plate-derived mesenchymal stem cells. Sci Rep 2015;5:14135.

23 Omenetti A, Diehl AM: The adventures of sonic hedgehog in development and repair. II. Sonic hedgehog and liver development, inflammation, and cancer. Am J Physiol Gastrointest Liver Physiol 2008;294:G595598.

24 Fleig SV, Choi SS, Yang L, Jung Y, Omenetti A, VanDongen HM, Huang J, Sicklick JK, Diehl AM: Hepatic accumulation of Hedgehog-reactive progenitors increases with severity of fatty liver damage in mice. Lab Invest 2007;87:1227-1239.

25 Ochoa B, Syn WK, Delgado I, Karaca GF, Jung Y, Wang J, Zubiaga AM, Fresnedo O, Omenetti A, Zdanowicz M: Hedgehog signaling is critical for normal liver regeneration after partial hepatectomy in mice. Hepatology 2010;51:1712-1723.

26 Omenetti A, Choi S, Michelotti G, Diehl AM: Hedgehog signaling in the liver. J Hepatol 2011;54:366-373.

27 Choi SS, Omenetti A, Syn WK, Diehl AM: The role of Hedgehog signaling in fibrogenic liver repair. Int J Biochem Cell Biol 2011;43:238-244.

28 Rodemann HP, Bamberg M: Cellular basis of radiation-induced fibrosis. Radiother Oncol 1995;35:83-90.

29 Yarnold J, Brotons MC: Pathogenetic mechanisms in radiation fibrosis. Radiother Oncol 2010;97:149-161.

30 Benson R, Madan R, Kilambi R, Chander S: Radiation induced liver disease: A clinical update. J Egypt Natl Canc Inst 2016;28:7-11.

31 Khozouz RF, Huq SZ, Perry MC: Radiation-induced liver disease. J Clin Oncol 2008;26:4844-4845.

32 Turek FW, Allada R: Liver has rhythm. Hepatology 2002;35:743-745.

33 Davidson AJ, Castanon-Cervantes 0, Stephan FK: Daily oscillations in liver function: diurnal vs circadian rhythmicity. Liver Int 2004;24:179-186.

34 Schmutz I, Albrecht U, Ripperger JA: The role of clock genes and rhythmicity in the liver. Mol Cell Endocrinol 2012;349:38-44.

35 Borovikova GV, Sidorenko GN: Effects of x-ray irradiation on circadian rhythm of the level of microsomal hemoproteins in the rat liver. Biull Eksp Biol Med 1990;110:653-655.

36 Ren ZG, Zhao JD, Gu K, Wang J, Jiang GL: Hepatic proliferation after partial liver irradiation in SpragueDawley rats. Mol Biol Rep 2012;39:3829-3836.

37 Langen B, Rudqvist N, Parris TZ, Helou K, Forssell-Aronsson E: Circadian rhythm influences genome-wide transcriptional responses to 131I in a tissue-specific manner in mice. EJNMMI Res 2015;5:75.

38 Tong X, Yin L: Circadian rhythms in liver physiology and liver diseases. Compr Physiol 2013;3:917-940. 


\section{Cellular Physiology Cell Physiol Biochem 2016;40:263-276 \begin{tabular}{l|l|l}
\hline DOI: 10.1159/000452543 & (c) 2016 The Author(s). Published by S. Karger AG, Basel
\end{tabular} and Biochemistry Published online: November 18, 2016 www.karger.com/cpb}

Kim et al.: Hh Signaling in FI-Induced Liver Damage

39 Tahara Y, Shibata S: Circadian rhythms of liver physiology and disease: experimental and clinical evidence. Nat Rev Gastroenterol Hepatol 2016;13:217-226.

40 Friedman SL: Mechanisms of hepatic fibrogenesis. Gastroenterology 2008;134:1655-1669.

41 Yang L, Wang Y, Mao H, Fleig S, Omenetti A, Brown KD, Sicklick JK, Li Y-X, Diehl AM: Sonic hedgehog is an autocrine viability factor for myofibroblastic hepatic stellate cells. J Hepatol 2008;48:98-106.

42 Omenetti A, Popov Y, Jung Y, Choi SS, Witek RP, Yang L, Brown KD, Schuppan D, Diehl AM: The hedgehog pathway regulates remodelling responses to biliary obstruction in rats. Gut 2008;57:1275-1282.

43 Jen KY, Cheung VG: Transcriptional response of lymphoblastoid cells to ionizing radiation. Genome Res 2003;13:2092-2100.

44 McDonald GB, Hinds MS, Fisher LD, Schoch HG, Wolford JL, Banaji M, Hardin BJ, Shulman HM, Clift RA: Veno-occlusive disease of the liver and multiorgan failure after bone marrow transplantation: a cohort study of 355 patients. Ann Intern Med 1993;118:255-267.

45 Rollins BJ: Hepatic veno-occlusive disease. Am J Med 1986;81:297-306.

46 Shulman HM, Fisher LB, Schoch HG, Henne KW, McDonald GB: Veno-occlusive disease of the liver after marrow transplantation: histological correlates of clinical signs and symptoms. Hepatology 1994;19:11711181.

47 Brooks SE, Miller CG, McKenzie K, Audretsch JJ, Bras G: Acute veno-occlusive disease of the liver. Fine structure in Jamaican children. Arch Pathol 1970;89:507-520.

48 Woods WG, Dehner LP, Nesbit ME, Krivit W, Coccia PF, Ramsay NK, Kim TH, Kersey JH: Fatal veno-occlusive disease of the liver following high dose chemotherapy, irradiation and bone marrow transplantation. Am J Med 1980;68:285-290.

49 McLean EK: The toxic actions of pyrrolizidine (senecio) alkaloids. Pharmacol Rev 1970;22:429-483.

50 Bras G, Jelliffe DB, Stuart KL: Veno-occlusive disease of liver with nonportal type of cirrhosis, occurring in Jamaica. AMA Arch Pathol 1954;57:285-300.

51 DeLeve LD, McCuskey RS, Wang X, Hu L, McCuskey MK, Epstein RB, Kanel GC: Characterization of a reproducible rat model of hepatic veno-occlusive disease. Hepatology 1999;29:1779-1791.

52 Oancea I, Png CW, Das I, Lourie R, Winkler I, Eri R, Subramaniam N, Jinnah H, McWhinney BC, Levesque J-P: A novel mouse model of veno-occlusive disease provides strategies to prevent thioguanine-induced hepatic toxicity. Gut 2013;62:594-605.

53 Hasan S, Kushwaha A: Response of irradiated diet fed rats to whole body X irradiation. Riv Radiol 1985;25:183-202.

54 Shulman H, Luk K, Deeg H, Shuman W, Storb R: Induction of hepatic veno-occlusive disease in dogs. Am J Pathol 1987;126:114-125.

55 Geraci JP, Mariano MS, Jackson KL: Hepatic radiation injury in the rat. Radiat Res 1991;125:65-72.

56 Guha C, Sharma A, Gupta S, Alfieri A, Gorla GR, Gagandeep S, Sokhi R, Roy-Chowdhury N, Tanaka KE, Vikram B, Roy-Chowdhury J: Amelioration of radiation-induced liver damage in partially hepatectomized rats by hepatocyte transplantation. Cancer Res 1999;59:5871-5874.

57 Epstein RB, Min KW, Anderson SL, Syzek L: A canine model for hepatic venoocclusive disease. Transplantation 1992;54:12-16.

58 Stephens LC, Peters LJ, Ang KK: Tolerance of rhesus monkey liver to ionizing radiation. Radiat Oncol Investig 1993;1:279-284.

59 Yannam GR, Han B, Setoyama K, Yamamoto T, Ito R, Brooks JM, Guzman-Lepe J, Galambos C, Fong JV, Deutsch M: A nonhuman primate model of human radiation-induced venocclusive liver disease and hepatocyte injury. Int J Radiat Oncol 2014;88:404-411. 